\title{
Nutritional value and microbiological profile of some locally prepared weaning-food mixtures
}

\author{
Osama Abdel Atty Rashwan and Mohamed Farag Mohamady
}

National Nutrition Institute, Cairo, Egypt

\begin{abstract}
Malnutrition is one of the most serious nutritional diseases among children especially during the weaning period. Ten weaning-food mixtures were prepared by using faba beans (Vicia faba L.) variety Giza; rice (Oryza sativa); corn (Zea mays) variety 320; lentil (Lens culinaris) were obtained from Agricultural Research Center, Giza, Cairo. Meanwhile, karish cheese (Cottage cheese); apple (Malus domistica) and Yellow carrots (Daucus carrota) were obtained from the local market, El-Obour City, Qalubia, Egypt.

Chemical composition of food materials ( $\mathrm{g} / 100 \mathrm{~g}$ on dry weight basis) indicated that: karish cheese powder recorded the highest percentage of protein (31.6\%) followed by lentil (26.2\%), faba bean (24.5\%), respectively. Meanwhile, carrots showed the highest percentage of crude fibers $(6.9 \%)$, followed by apple peel (4.0\%). Rice had the highest percentage of carbohydrates $(88.5 \%)$. The highest value of calories was found in corn ( $411.5 \mathrm{kcal})$, followed by rice $(401.7 \mathrm{kcal})$. Cereals are rich in carbohydrates and are the main source of energy.

Moreover, consuming $100 \mathrm{~g}$ from any of the ten prepared formulae could cover the daily requirements for infants (6 - 12 months) from proteins and about half or more of the required energy according to FAO/WHO, (1989), which recorded that babies need from $(13-14 \mathrm{~g})$ protein and $(650-850$ kilo calories).

Total bacterial counts of all formulae mixtures ranged between (31 and 61), while psychrophilic bacteria ranged between (22 and 44). Microbiological evaluation showed that all formulae were in the permissible limits according to the recommendations of Egyptian Organization for Standardization and Quality Control. Also, results showed that the total bacterial counts were less than $1000 \mathrm{cell} / \mathrm{g}$ in all formulae. Coliform bacteria, fungi and yeasts were not detected in all samples and had a negative presumptive test for the presence of coliform bacteria, fungi and yeasts. These results may partially be due to the effect of heat treatments during the preparation of mixtures and mainly due to heat sterilization of final food mixtures.
\end{abstract}

\section{Introduction}

Malnutrition is one of the most serious nutritional diseases among children. It affects the overall-health beginning from infanthood to childhood stage (Farag, 1999). One of the major nutritional problems facing the developing countries today is the limited sources of protein. A relatively high-percentage of children suffers from protein and energy deficiency (WHO, 1991).

Nearly $30 \%$ of humanity in the developing world suffers from one or more forms of malnutrition, a considerable proportion were children under 5 years of age according to Nazih and Rashed, (2000). In Egypt, Hammad, (1997) recorded that malnutrition is one of the most serious child health problems, particularly among young children, together with infectious diseases that leads to high morbidity and mortality in early childhood. 


\section{Osama Abdel Atty Rashwan and Mohamed Farag Mohamady}

The aim of this study is concerned with preparing some baby food mixtures of high nutritional value and good quality by using cereals (rice and corn); legumes (lentil and bean); karish cheese; carrots and apple peel powder) for infants during the weaning stage.

\section{Materials and Methods}

\section{Materials}

The raw materials used throughout the present study for the preparation of the ten formulae were as follows:

Corn (Zea mays, variety 320) was obtained from Agricultural Research Center, Giza, Cairo.

Rice (Oryza sativa) was obtained from Agricultural Research Center, Giza, Cairo.

Broad beans (Vicia faba, L.) were obtained from Agricultural Research Center, Giza, Cairo.

Lentil (Lens culinaris) was obtained from Agricultural Research Center, Giza, Cairo.

Karish Cheese (Cottage cheese) was obtained from the local market at El-Obour City, Qalubia Governorate, Egypt.

Apple peels (Malus domestica) and yellow carrots (Daucus carrot) were obtained from the local market at El-Obour City, Qalubia Governorate, Egypt.

Also, baby foods (11) and (12) (table 4) were obtained from the local market (wheat cereal with milk).

\section{Preparation of materials}

Corn, rice, broad beans, lentil and apple peels were cleaned from impurities and washed several times with tap water. After adding the karish cheese for the mixture, it was boiled for an hour until the swelling of the grains. The meal was taken and the remaining water was removed. The prepared food formulae were air dried at room temperature for 24 hours under ventilation conditions, then dried in an electrical oven at $50^{\circ} \mathrm{C}$ for 96 hours. This was ready for the analysis.

Table (1):

The percentage of materials in the ten weaning food formulae:

\begin{tabular}{|c|c|c|c|c|c|c|c|}
\hline Fomula No. Foods & Corn & Rice & Faba Bean & Lentil & $\begin{array}{l}\text { Karish } \\
\text { cheese }\end{array}$ & Carrots & $\begin{array}{l}\text { Apple } \\
\text { peels }\end{array}$ \\
\hline 1 & 30 & 25 & 25 & 20 & - & - & - \\
\hline 2 & 25 & 25 & 20 & 18 & 12 & - & - \\
\hline 3 & 25 & 25 & 20 & 18 & - & 12 & - \\
\hline 4 & 25 & 25 & 20 & 18 & - & - & 12 \\
\hline 5 & 25 & 25 & 20 & 18 & 6 & 6 & - \\
\hline 6 & 25 & 25 & 20 & 18 & - & 6 & 6 \\
\hline 7 & 25 & 25 & 20 & 18 & 6 & - & 6 \\
\hline 8 & 25 & 25 & 20 & 18 & 4 & 4 & 4 \\
\hline 9 & 25 & 25 & 20 & 18 & 6 & 3 & 3 \\
\hline 10 & 25 & 25 & 20 & 18 & 3 & 6 & 3 \\
\hline
\end{tabular}

Methods:

Chemical analysis:

Moisture content:

Moisture content of prepared weaning foods was determined according to the methods described by AOAC, (1990) as weight loss of 10 gram samples after drying at $105^{\circ} \mathrm{C}$ in the electricity oven until constant weight. 


\section{Egypt. J. of Nutrition and Health Vol. 10 No. 1 (2015)}

\section{Crude protein:}

Protein content of prepared weaning food mixtures was performed by macro-kjeldahl method as described by AOAC, (1995). The protein content was calculated by multiplying the nitrogen content by 6.25 and the results express as protein percentage (\%).

Total lipids:

Lipids of prepared weaning mixtures were calculated from prepared weaning food formulae according to the method of Bligh and Dyer, (1959). Total lipids in all samples were calculated by using the following equation:

Total lipids $\%=\frac{\text { Weight of lipids }}{\text { Weight of samples }} \times 100$

Ash and Crude fibers:

Ash and crude fibers were determined as described by the method of $A O A C,(2000)$.

\section{Carbohydrates:}

Carbohydrate content of prepared weaning food mixtures was calculated by the difference according to the following equation:

Total Carbohydrates $=100-($ protein + lipids + ash and crude fibers $)$.

\section{Energy value:}

Energy value was estimated by the following equation according to (FAO/WHO, 1985).

Energy value $=(\%$ Carbohydrates $\times 4.0+\%$ protein $\times 4.0+\%$ fats $\times 9.0)$.

\section{Determination of minerals:}

Calcium content was determined using flame photometry method (Barauh and Borah, 1998), while iron and magnesium were determined by Atomic Absorption Spectrophotometer. Standard colorimetric method was employed for phosphorus (Thimmaiah, 1999).

\section{Determination of amino acids:}

Amino acid determination of the reported formulae was performed according to the method of Winder and Eggum, (1966). Oxidation with performic acid to protect methionine and cysteine from destruction, followed by acid hydrolysis was carried out in a closed screw capped tubes for determining all amino acids other than tryptophan. A sample of $20-30 \mathrm{mg}$ of dried and defatted samples was weighed in the screw capped tubes, and $5 \mathrm{ml}$ of performic acid were added. The tubes were closed and placed in ice water bath for 16 hours. Sodium metabisulfate were added to the oxidized mixture. The tubes were placed in an oven at $110^{\circ} \mathrm{C}$ for 24 hours. The tubes were then opened and the content was then evaporated for dryness in a rotary evaporator. A suitable volume of sodium citrate buffer ( $\mathrm{pH} 2.2)$ was added to the dried film of the hydrolyzed sample. After all the soluble materials completely dissolved, the sample was ready for analysis. The system used for the analysis was High Performance Amino Acid Analyzer, Biochrom 20 and Pharmacia Biotech constructed at The National Center for Radiation Research and Technology (NCRRT), Atomic Energy Authority, Egypt.

\section{Microbiological evaluation of weaning food mixtures: \\ Microbiological evaluation of the prepared weaning-food mixtures and the two local market samples (11 and 12)} was determined according to ICMSF, (1978). 


\section{Results and Discussion}

Chemical composition of food materials ( $\mathrm{g} / 100 \mathrm{gm}$ on dry weight basis) is shown in table (2). It could be seen from these results that: the percentage of moisture content, crude protein, total lipids, ash content, crude fibers and carbohydrates for rice were $6.5,8.1,1.7,0.9,0.8$ and $88.5 \%$ respectively. These results were in agreement with those found by Farag, (1999) and Allam, (2007). That for corn was protein 10.5, lipids 4.7, ash 1.6, fibers 1.4 and carbohydrates $81.8 \%$. These results were in agreement with those obtained by Doweider, (2001), Daoud, (2002) and Khalil and Hussein, (2003)

Results in the same table showed that the chemical composition of faba bean was protein, lipids, ash, fibers and carbohydrates were $24.5 \%, 1.2 \%, 4.9 \%, 1.9 \%$ and $67.5 \%$ respectively. Meanwhile, lentil was $26.2 \%, 0.5 \%, 4.1 \%$, $1.0 \%$ and $68.2 \%$, respectively.

It could be observed that the percentage of protein, lipids, ash, fibers and carbohydrates for karish cheese were $31.6 \%, 4.5 \%, 8.3 \%$ and $55.6 \%$, respectively. These results were similar to those reported by Emam, (1997).

Results showed that protein, lipids, ash, fibers and carbohydrates of carrots powder were also $7.5 \%, 2.1 \%$, $7.1 \%, 6.9 \%$ and $76.4 \%$ (g/100g on dry weight basis) respectively. Also, these results were in agreement with those found by Ismail, et al., (2000) and Abou-Sebaa, (2004). The chemical analysis of apple peels powder showed that protein was $5.1 \%$, lipids $1.8 \%$, ash $4.5 \%$, fibers $4.0 \%$ and carbohydrates $84.6 \%$. These results were in agreement with those found by Gorinstein et al., (2001). Total energy was the highest value in corn ( 411.5 kilo calories) followed by rice (401.8 kilo calories). In contrast, carrots showed the lowest value of total energy (354.5 kilo calories) in $100 \mathrm{~g}$ on dry weight basis.

Generally, from the above mentioned results, it could be observed that: rice and corn are rich in carbohydrates, while faba bean and lentil are rich in plant protein. Moreover, karish cheese is considered as a good source of animal protein $(31.6 \mathrm{~g})$ and ash $(8.3 \mathrm{~g} / 100 \mathrm{~g}$ on dry weight basis). Moreover, carrots and apple peels are considered a good source of ash and fiber content.

Table (2):

Chemical composition of raw food materials (g/100g on dry weight basis)

\begin{tabular}{|l|l|l|l|l|l|l|l|}
\hline $\begin{array}{l}\text { Foods } \\
\text { powder }\end{array}$ & $\begin{array}{c}\text { Moisture } \\
\text { content }\end{array}$ & $\begin{array}{c}\text { Crude } \\
\text { protein }\end{array}$ & Total lipids & Ash content & Crude fibers & $\begin{array}{c}\text { Carbohy- } \\
\text { drates }\end{array}$ & $\begin{array}{c}\text { Total energy } \\
\text { (Cal.) }\end{array}$ \\
\hline Corn & 8.10 & 10.5 & 4.70 & 1.60 & 1.40 & 81.8 & 411.5 \\
\hline Rice & 6.50 & 8.10 & 1.70 & 0.90 & 0.80 & 88.5 & 401.80 \\
\hline Faba Bean & 8.40 & 24.5 & 1.20 & 4.90 & 1.90 & 67.5 & 378.8 \\
\hline Lentil & 7.50 & 26.2 & 0.50 & 4.10 & 1.00 & 68.2 & 382.1 \\
\hline $\begin{array}{l}\text { Karish cheese } \\
\text { powder }\end{array}$ & 4.50 & 31.60 & 4.50 & 8.30 & 0.00 & 55.6 & 389.3 \\
\hline Carrots powder & 6.10 & 7.50 & 2.10 & 7.10 & 6.90 & 76.4 & 354.5 \\
\hline Apple peels & 5.50 & 5.10 & 1.80 & 4.50 & 4.00 & 84.6 & 375 \\
\hline
\end{tabular}




\section{Egypt. J. of Nutrition and Health Vol. 10 No. 1 (2015)}

Mineral constituents of raw food materials $(\mathrm{mg} / 100 \mathrm{~g}$ on dry weight basis) were tabulated in table (3). From the results, calcium of studied food items ranged between 120 and $470 \mathrm{mg}$, phosphorus (120 - $352 \mathrm{mg}$ ), magnesium (94 $319 \mathrm{mg})$ and iron $(2.76-23.9 \mathrm{mg})$. The highest value of $(\mathrm{Ca})$ was found in karish cheese powder $(470 \mathrm{mg})$ and the lowest value was found in faba bean $(120 \mathrm{mg})$. Meanwhile, the highest value of phosphorus was also found in karish cheese powder (352 mg) and the lowest value was found in corn (120 mg).

The highest value of $(\mathrm{Mg})$ was found in faba bean $(319 \mathrm{mg} / 100 \mathrm{~g}$ on dry weight basis), and the lowest value was observed in lentil $(94 \mathrm{mg})$. It could be seen from these results that: apple peels powder showed the highest value of micro elements of iron $(23.9 \mathrm{mg})$ and the lowest value was noticed in karish cheese $(2.46 \mathrm{mg})$. It could be concluded that: apple peels is considered a good source of iron and karish cheese is a rich source of both $\mathrm{Ca}$ and $\mathrm{P}$.

Table (3):

Mineral composition of raw food materials ( $\mathrm{mg} / 100 \mathrm{~g}$ on dry weight basis)

\begin{tabular}{|l|l|l|l|l|}
\hline \multicolumn{1}{|c|}{ Foods powder } & & & & \multicolumn{2}{c|}{ Mg } & \\
\hline Corn & & & & Fe \\
\hline Rice & 360 & 120 & 128 & 3.60 \\
\hline Bean & 390 & 149 & 230 & 4.08 \\
\hline Lentil & 120 & 253 & 319 & 5.52 \\
\hline Karish cheese & 260 & 182 & 94 & 5.70 \\
\hline Carrots & 470 & 352 & 144 & 2.76 \\
\hline Apple peels & 240 & 330 & 168 & 22.60 \\
\hline
\end{tabular}

The chemical composition of prepared weaning-foods and local baby mixtures ( $\mathrm{g} / 100 \mathrm{~g}$ on dry weight basis) is shown in table (4). Total protein ranged from (15.2 to $17.8 \mathrm{~g})$; total lipids $(1.70-1.90 \mathrm{~g})$; ash content $(2.60-2.87 \mathrm{~g})$; crude fibers $(1.85-2.96 \mathrm{~g})$; total carbohydrates $(74.47-78.16 \mathrm{~g})$ and moisture content $(3.80-4.15 \%)$. The same trends of results are in agreement with those found by Freig, (2002); Emam, (2002) and Abou-Sebaa, (2004). Also, such results are coincident with those recommended by Egyptian Organization Standard (EOS, 1998). Moreover, consuming $100 \mathrm{~g}$ from any formula could cover the daily requirements for a baby (6-12 months) from protein and half or more from total energy according to FAO/WHO, (1989), which recommended that the daily requirements for this age ranged between $(13-14 \mathrm{~g})$ protein and $(650-850$ kilo calories) during the first year.

The obtained results indicated that prepared formula number (2) recorded the highest value of protein (17.8\%) and ash content $(2.87 \%)$. This may be due to the addition of karish cheese which is rich in protein and minerals as shown previously in table (2). It appeared that the protein content of all formulae was not less than $15.2 \%$ which could be over the daily requirements of babies as recommended by FAO/WHO, (1989).

Results in the same table revealed that formula number (2) recorded the highest value of crude fibers $(2.96 \%)$ as compared with the other formulae either in prepared or local baby foods. This may be due to the addition of karish cheese with the higher percentage (12\%). The obtained results were in agreement with those found by Ismail, et al., (2000) and Freig, (2002).

Moreover, both prepared and local baby food mixtures are rich in ash content. Also, formula number (2) recorded the highest percentage of crude protein, crude fibers and ash content as compared with the other prepared sample and commercial baby foods. 
Statistical analysis of the data indicated that there was a significant difference at $p \leq 0.05$ among protein, ash and fiber content. In contrast, moisture, lipids, carbohydrates and total energy of all prepared and local weaning-foods were not significantly different.

On the other hand, the differentiation in caloric values of different weaning food mixtures as shown in the same table ranged between 386.2 and 391.1 kilo calories/100 g sample. Prepared formula number (1) and (7) recorded the highest value of total calories 390.6 and 390.7 . This may be the highest percentage of carbohydrates in No. (1) compared with No. (7), but in No. (7) the protein is higher than No. (1).

Table (4):

Chemical composition of both prepared weaning-food mixtures and local baby foods (g/100g on dry weight basis)

\begin{tabular}{|c|c|c|c|c|c|c|c|}
\hline Formula No. Constituents & $\begin{array}{l}\text { Moisture } \\
\text { content }\end{array}$ & $\begin{array}{c}\star \star \star \star \\
\text { Crude } \\
\text { protein }\end{array}$ & $\begin{array}{c}\star \star \star \\
\text { Total } \\
\text { lipids }\end{array}$ & Ash content & Crude fibers & $\begin{array}{c}{ }^{\star \star \star} \\
\text { Carbohydrates }\end{array}$ & $\begin{array}{c}\star \star \star \star \\
\text { Total energy }\end{array}$ \\
\hline 1 & 3.80 & 15.5 & 1.80 & 2.60 & 2.01 & 78.09 & 390.6 \\
\hline 2 & 3.96 & 17.8 & 1.90 & 2.87 & 2.96 & 74.47 & 386.2 \\
\hline 3 & 3.91 & 15.2 & 1.82 & 2.80 & 2.02 & 78.16 & 389.8 \\
\hline 4 & 4.15 & 15.3 & 1.83 & 2.81 & 2.05 & 78.01 & 390.3 \\
\hline 5 & 4.01 & 17.1 & 1.79 & 2.82 & 1.91 & 76.38 & 390.0 \\
\hline 6 & 4.06 & 15.5 & 1.77 & 2.66 & 2.01 & 78.06 & 390.2 \\
\hline 7 & 3.98 & 17.2 & 1.70 & 2.61 & 1.85 & 76.64 & 390.7 \\
\hline 8 & 3.95 & 16.3 & 1.88 & 2.80 & 1.92 & 77.10 & 390.5 \\
\hline 9 & 4.15 & 17.5 & 1.75 & 2.85 & 1.87 & 76.03 & 389.9 \\
\hline 10 & 4.09 & 16.9 & 1.83 & 2.70 & 2.00 & 76.57 & 390.4 \\
\hline${ }^{\star}(11)$ & 4.02 & 15.9 & 1.90 & 2.65 & 1.95 & 77.06 & 391.1 \\
\hline \multirow[t]{2}{*}{$\star \star(12)$} & 4.10 & 15.5 & 1.81 & 2.80 & 2.00 & 77.89 & 389.9 \\
\hline & NS & $\mathrm{S}$ & NS & $S$ & $S$ & NS & NS \\
\hline \multicolumn{8}{|c|}{${ }^{\star}$ Local Sample (11) } \\
\hline \multicolumn{8}{|c|}{${ }^{\star \star \star}$ On dry weight basis } \\
\hline
\end{tabular}

Minerals of prepared weaning-food and baby mixtures ( $\mathrm{mg} / 100 \mathrm{~g}$ on dry weight basis) were recorded in table (5). Prepared formulae and local baby food mixtures indicated that: calcium ranged between (120 and $310 \mathrm{mg} / 100 \mathrm{~g}$ on dry weight basis). Formula (2) showed the highest value of $\mathrm{Ca}$ as compared with prepared and local market baby food mixtures. This may be due to the higher percentage of added karish cheese powder which is rich in calcium as shown in the previously table (2). These obtained results are in agreement with those obtained by Freig, (2002).

Phosphorus of all samples ranged between (108 and $246 \mathrm{mg} / 100 \mathrm{~g}$ on dry weight basis). Also, formula (2) recorded the highest value as compared with prepared and local baby foods. This may be due to the addition of karish cheese powder.

Also, table (5) showed that magnesium of all prepared formulae and local baby foods ranged between (68 and $136 \mathrm{mg} / 100 \mathrm{~g}$ on dry weight basis). Also, formula (2) showed the highest value of $\mathrm{Mg}$ among all samples, while formula (6) recorded the lowest value of all samples. This may be due to its being void of karish cheese. 


\section{Egypt. J. of Nutrition and Health Vol. 10 No. 1 (2015)}

It could be seen from these results that: iron in both prepared and local baby foods ranged between (5.17 and $6.16 \mathrm{mg} / 100 \mathrm{~g}$ on dry weight basis). Formula (4) recorded the highest value in iron. This may be due to the addition of apple peels powder with the highest percentage (12\%) and apple is considered a good source of iron. Meanwhile, formula (7) showed the lowest value in iron.

It is worthy mentioning that: some prepared weaning mixtures recorded higher percentage of $\mathrm{Ca}, \mathrm{P}, \mathrm{Mg}$ and $\mathrm{Fe}$ than those found in commercial baby foods, especially formula No. (2) and (4), besides being less expensive than the commercial baby foods.

Moreover, consuming $100 \mathrm{~g}$ from any formula could cover about half or more of the daily requirements of iron according to FAO/WHO, (1989). Meanwhile, magnesium could cover all daily requirements of babies. Calcium covers about 20 to $51.7 \%$ and phosphorus $21.6-49.2 \%$ of the daily requirements.

It could be concluded that: formula (2) was the best formula which recorded the highest value of $\mathrm{Ca}, \mathrm{P}$ and $\mathrm{Mg}$ as compared with either prepared or local baby foods. This may be due to the addition of karish cheese. Also, formula (4) recorded the highest value of iron as compared with the other samples. This may be due to the addition of apple peels powder. In general, from the above mentioned results, it could be observed that all prepared weaning-foods are considered a good source of minerals vital for the first stage of childhood as supplementary foods. The achieved results of different prepared weaning-foods are in agreement with those obtained from the local baby foods.

Table (5):

Minerals of prepared weaning food mixtures and local baby foods (mg/100g on dry weight basis)

\begin{tabular}{|c|c|c|c|c|}
\hline Formula No. Minerals & $\mathrm{Ca}$ & $P$ & $\mathrm{Mg}$ & $\mathrm{Fe}$ \\
\hline $\begin{array}{c}1 \\
(\mathrm{RDA} \%)\end{array}$ & $\begin{array}{r}190 \\
31.7\end{array}$ & $\begin{array}{r}133 \\
26.6 \\
\end{array}$ & $\begin{array}{l}123 \\
205\end{array}$ & $\begin{array}{l}5.92 \\
59.2\end{array}$ \\
\hline $\begin{array}{c}2 \\
(\text { RDA \%) }\end{array}$ & $\begin{array}{l}310 \\
51.7\end{array}$ & $\begin{array}{l}246 \\
49.2\end{array}$ & $\begin{array}{c}136 \\
226.7\end{array}$ & $\begin{array}{l}5.75 \\
57.5\end{array}$ \\
\hline $\begin{array}{c}3 \\
(\text { RDA \%) }\end{array}$ & $\begin{array}{l}200 \\
33.3\end{array}$ & $\begin{array}{l}133 \\
26.6\end{array}$ & $\begin{array}{c}112 \\
186.7\end{array}$ & $\begin{array}{l}5.22 \\
52.2\end{array}$ \\
\hline $\begin{array}{c}4 \\
\text { (RDA \%) }\end{array}$ & $\begin{array}{l}140 \\
23.3\end{array}$ & $\begin{array}{l}108 \\
21.6\end{array}$ & $\begin{array}{l}114 \\
190\end{array}$ & $\begin{array}{l}6.16 \\
61.6\end{array}$ \\
\hline $\begin{array}{c}5 \\
\text { (RDA \%) }\end{array}$ & $\begin{array}{l}200 \\
33.3\end{array}$ & $\begin{array}{l}153 \\
30.6\end{array}$ & $\begin{array}{l}123 \\
205\end{array}$ & $\begin{array}{l}5.67 \\
56.7\end{array}$ \\
\hline $\begin{array}{c}6 \\
\text { (RDA \%) }\end{array}$ & $\begin{array}{l}250 \\
41.7\end{array}$ & $\begin{array}{l}175 \\
35.0\end{array}$ & $\begin{array}{c}68 \\
113.3\end{array}$ & $\begin{array}{l}5.34 \\
53.4\end{array}$ \\
\hline $\begin{array}{c}7 \\
\text { (RDA \%) }\end{array}$ & $\begin{array}{l}180 \\
30.0\end{array}$ & $\begin{array}{r}133 \\
26.6\end{array}$ & $\begin{array}{c}73.0 \\
121.7\end{array}$ & $\begin{array}{l}5.17 \\
51.7\end{array}$ \\
\hline $\begin{array}{c}8 \\
\text { (RDA \%) }\end{array}$ & $\begin{array}{l}120 \\
20.0\end{array}$ & $\begin{array}{l}120 \\
24.0 \\
\end{array}$ & $\begin{array}{c}98 \\
163.3 \\
\end{array}$ & $\begin{array}{l}5.58 \\
55.8 \\
\end{array}$ \\
\hline $\begin{array}{c}9 \\
(\text { RDA \%) }\end{array}$ & $\begin{array}{l}170 \\
28.3\end{array}$ & $\begin{array}{l}153 \\
30.6\end{array}$ & $\begin{array}{c}69 \\
115\end{array}$ & $\begin{array}{l}5.49 \\
54.9\end{array}$ \\
\hline $\begin{array}{c}10 \\
\text { (RDA \%) }\end{array}$ & $\begin{array}{r}170 \\
28.3 \\
\end{array}$ & $\begin{array}{r}186 \\
37.2 \\
\end{array}$ & $\begin{array}{c}121 \\
201.7 \\
\end{array}$ & $\begin{array}{l}5.39 \\
53.9 \\
\end{array}$ \\
\hline $\begin{array}{c}{ }^{*}(11) \\
(\mathrm{RDA} \%)\end{array}$ & $\begin{array}{l}260 \\
43.3\end{array}$ & $\begin{array}{l}174 \\
34.8\end{array}$ & $\begin{array}{c}96 \\
160\end{array}$ & $\begin{array}{l}5.47 \\
54.7\end{array}$ \\
\hline $\begin{array}{c}{ }^{\star \star}(12) \\
(\mathrm{RDA} \%)\end{array}$ & $\begin{array}{l}200 \\
33.3\end{array}$ & $\begin{array}{l}120 \\
24.0\end{array}$ & $\begin{array}{c}115 \\
191.7\end{array}$ & $\begin{array}{l}5.85 \\
58.5\end{array}$ \\
\hline RDA & 600 & 500 & 60 & 10 \\
\hline
\end{tabular}

RDA: Recommended daily allowance per $\mathrm{mg}$ for babies $(6-12)$ months according to FAO/WHO, (1989) 


\section{Osama Abdel Atty Rashwan and Mohamed Farag Mohamady}

Tabie (6) shows amino acids content (A.A) of prepared weaning foods and local market baby food mixtures (mg/100g on dry weight basis). Results revealed that seventeen amino acids were identified by using Amino Acid Analyzer. The predominant compounds of essential amino acids (EAA) were leucine $(33.75-59.8 \mathrm{mg})$ and lysine (12.7 - $24.7 \mathrm{mg})$, While, glutamic acid was (13.6 - $18.0 \mathrm{mg})$ and asparatic acid was (11.2 - $18.2 \mathrm{mg})$ of non-essential amino acids (NEAA). The total EAA ranged between (107 and $19.5 \mathrm{mg}$ ), whereas, total NEAA ranged between (64.4-96.2 $\mathrm{mg}$ ). Results showed that EAA of blends increased with the increase in the amount of karish cheese which is the main source of EAA. Total EAA was best found in formula (2) followed by formulae 7, 8, 6 and 5, respectively. It is worthy mentioning that: all prepared formulae recorded higher values of EAA as compared to these of two local baby food mixtures. Moreover, consuming $100 \mathrm{~g}$ of any formula could cover the daily requirements allowance from EAA for babies except methionine and cysteine as recommended by FAO/WHO, (1989).

Table (6):

Amino acids of prepared weaning-food mixtures and local baby food mixtures ( $\mathrm{mg} / 100 \mathrm{~g}$ on dry weight basis)

\begin{tabular}{|c|c|c|c|c|c|c|c|c|c|c|c|}
\hline Formula No. & 1 & 2 & 3 & 4 & 5 & 6 & 7 & 8 & *1 & **2 & ${ }^{\star \star \star *} \mathrm{RDA}$ \\
\hline \multicolumn{12}{|c|}{ Essential amino acids (EAA) } \\
\hline Valine & 13.0 & 15.6 & 12.5 & 9.75 & 10.4 & 14.3 & 14.3 & 15.6 & 10.4 & 10.4 & 5.5 \\
\hline Methionine & 0.0 & 0.0 & 0.0 & 0.75 & 0.0 & 0.0 & 0.0 & 2.00 & 1.80 & 1.80 & 4.2 \\
\hline Cysteine & 2.0 & 4.5 & 2.0 & 2.0 & 4.8 & 2.0 & 3.6 & 0.0 & 0.0 & 0.0 & 4.2 \\
\hline Isoleucine & 15.0 & 18.2 & 14.0 & 12.0 & 16.0 & 16.5 & 15.4 & 18.0 & 12.8 & 12.0 & 4.6 \\
\hline Leucine & 35.0 & 59.8 & 44.0 & 33.75 & 44.8 & 49.5 & 49.5 & 54.0 & 36.8 & 37.6 & 9.3 \\
\hline Tyrosine & 15.0 & 14.3 & 2.0 & 1.50 & 9.60 & 4.40 & 13.2 & 1.20 & 6.40 & 3.0 & 7.2 \\
\hline Phenylalanine & 18.0 & 22.1 & 14.0 & 12.0 & 12.8 & 18.7 & 18.7 & 19.2 & 14.4 & 12.8 & 7.2 \\
\hline Histidine & 19.0 & 22.1 & 15.0 & 12.75 & 13.6 & 19.8 & 22 & 20.4 & 15.2 & 16.0 & 2.6 \\
\hline Lysine & 20.0 & 24.7 & 16.0 & 12.75 & 14.4 & 20.9 & 20.9 & 20.4 & 15.2 & 15.2 & 4.3 \\
\hline Threonine & 13.0 & 18.2 & 11.0 & 9.75 & 11.2 & 14.3 & 12.1 & 14.4 & 8.0 & 11.2 & 44.3 \\
\hline Total EAA & 150.0 & 199.5 & 130.5 & 107.0 & 137.6 & 160.4 & 169.7 & 165.2 & 121.0 & 120.2 & 93.4 \\
\hline \multicolumn{12}{|c|}{ Nonessential amino acids (NEAA) } \\
\hline Asparatic & 17.0 & 18.2 & 14.2 & 12.0 & 13.6 & 17.6 & 15.4 & 16.8 & 11.2 & 11.2 & \\
\hline Serine & 13.0 & 13.0 & 11.0 & 9.75 & 10.4 & 14.3 & 9.90 & 14.4 & 6.4 & 10.4 & \\
\hline Glutamic & 18.0 & 16.9 & 15.0 & 17.8 & 13.6 & 17.6 & 16.5 & 18.0 & 13.6 & 13.6 & \\
\hline Proline & 4.0 & 2.60 & 4.0 & 5.25 & 5.60 & 5.5 & 3.3 & 6.0 & 4.4 & 6.4 & \\
\hline Glycine & 10.0 & 11.7 & 8.0 & 6.0 & 7.20 & 9.90 & 9.9 & 9.6 & 7.2 & 7.2 & \\
\hline Alanine & 9.0 & 9.10 & 8.0 & 6.75 & 7.20 & 9.90 & 9.9 & 9.6 & 7.2 & 7.2 & \\
\hline Arginine & 17 & 24.7 & 16.0 & 17.7 & 16.0 & 19.8 & 20.9 & 19.2 & 14.4 & 14.4 & \\
\hline Total NEAA & 88 & 96.2 & 76.0 & 75.3 & 73.6 & 94.6 & 85.8 & 93.6 & 64.4 & 70.4 & \\
\hline Total AA & 238 & 295.7 & 206.7 & 182.2 & 211.2 & 255 & 282.5 & 258.8 & 185.4 & 190.6 & \\
\hline
\end{tabular}

* Local market sample (1)

** Local market sample (2)

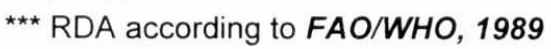




\section{Microbiological examination}

Microbiological examination of this was done in the formulae after being cooked. Total bacterial counts were shown in table (8). The obtained results revealed that total bacterial counts of all blend mixtures ranged between 31 and 61 at zero time, while total bacterial counts slightly increased in all formulae that ranged between 50 and 70 at the end of the storage. All blends showed that total bacterial counts were in the permissible limit according to the recommendations of The Egyptian Organization Standard EOS, (1992 and 1998). Also, results showed that total bacterial counts were less than $1000 \mathrm{cell} / \mathrm{g}$ in all blends either at zero time or during subsequent storage period. The general rule is that all blends should be microbiologically safe for children consumption (Farag et al., 1998) and (Emam, 2002). These results may be partially due to the effect of heat treatment during the preparation of weaning food mixtures and also heat sterilization of final blend food mixtures. It is worthy mentioning that total bacterial counts of commercial weaning foods were relatively higher than those found in prepared blends.

Table (8):

Total bacterial counts elevation of prepared weaning-foods (cell/g) during storage period

\begin{tabular}{|c|c|c|c|c|}
\hline Formula No. & Zne month & Two months & Three months \\
\hline 1 & & & & $5.0 \times 10$ \\
\hline 2 & $3.1 \times 10$ & $3.5 \times 10$ & $4.8 \times 10$ & $5.2 \times 10$ \\
\hline 3 & $4.2 \times 10$ & $4.5 \times 10$ & $4.9 \times 10$ & $6.0 \times 10$ \\
\hline 4 & $4.0 \times 10$ & $4.7 \times 10$ & $5.6 \times 10$ & $6.1 \times 10$ \\
\hline 5 & $5.1 \times 10$ & $5.5 \times 10$ & $5.9 \times 10$ & $6.0 \times 10$ \\
\hline 6 & $5.2 \times 10$ & $5.4 \times 10$ & $5.8 \times 10$ & $5.8 \times 10$ \\
\hline 7 & $4.7 \times 10$ & $4.9 \times 10$ & $5.3 \times 10$ & $6.2 \times 10$ \\
\hline 8 & $4.3 \times 10$ & $5.0 \times 10$ & $5.5 \times 10$ & $6.1 \times 10$ \\
\hline 9 & $5.3 \times 10$ & $5.4 \times 10$ & $5.8 \times 10$ & $6.8 \times 10$ \\
\hline 10 & $5.6 \times 10$ & $5.8 \times 10$ & $6.4 \times 10$ & $6.0 \times 10$ \\
\hline$*(11)$ & $4.8 \times 10$ & $5.1 \times 10$ & $5.5 \times 10$ & $7.0 \times 10$ \\
\hline$* *(12)$ & $5.9 \times 10$ & $6.2 \times 10$ & $6.1 \times 10$ & $6.9 \times 10$ \\
\hline
\end{tabular}

* Local baby food mixtures (11)

** Local baby food mixtures (12)

Total psychrophilic bacterial counts were shown in table (9). The obtained data showed that total psychrophilic bacterial counts of all blends either prepared or commercial weaning-foods ranged from 22 to 44 before storage period. Meanwhile, a slight increase in the number of psychrophilic bacterial counts was observed during the subsequent storage period till it reached from 31 to 59 at the end of the storage. All blends either prepared or commercial weaning foods were in the permissible limits according to the recommendations of The Egyptian Organization Standard EOS, (1998), which reported that the number of bacteria should be less than $1000 \mathrm{cell} / \mathrm{g}$ of any formula and also microbiologically safe for children consumption. It is worthy mentioning that local-weaning foods mixtures contained the highest number of psychrophilic bacteria among all prepared mixtures. 
Table (9):

Total psychrophilic bacterial counts of prepared weaning foods and local baby foods (cell/g) during storage period

\begin{tabular}{|c|c|c|c|c|}
\hline Formula No. Storage Period & Zero time & One month & Two months & Three months \\
\hline 1 & & & & $3.1 \times 10$ \\
\hline 2 & $2.2 \times 10$ & $2.4 \times 10$ & $3.9 \times 10$ & $4.0 \times 10$ \\
\hline 3 & $3.0 \times 10$ & $3.2 \times 10$ & $3.9 \times 10$ & $4.1 \times 10$ \\
\hline 4 & $3.2 \times 10$ & $3.5 \times 10$ & $3.5 \times 10$ & $4.0 \times 10$ \\
\hline 5 & $3.1 \times 10$ & $3.5 \times 10$ & $4.9 \times 10$ & $5.0 \times 10$ \\
\hline 6 & $4.2 \times 10$ & $4.5 \times 10$ & $5.0 \times 10$ & $5.5 \times 10$ \\
\hline 7 & $4.3 \times 10$ & $4.4 \times 10$ & $3.7 \times 10$ & $4.2 \times 10$ \\
\hline 8 & $3.2 \times 10$ & $3.5 \times 10$ & $5.1 \times 10$ & $5.4 \times 10$ \\
\hline 9 & $4.2 \times 10$ & $5.0 \times 10$ & $4.5 \times 10$ & $5.0 \times 10$ \\
\hline 10 & $4.1 \times 10$ & $4.0 \times 10$ & $5.1 \times 10$ & $5.0 \times 10$ \\
\hline$\star(11)$ & $3.8 \times 10$ & $4.5 \times 10$ & $5.1 \times 10$ & $5.9 \times 10$ \\
\hline$*(12)$ & $4.2 \times 10$ & $4.9 \times 10$ & $5.4 \times 10$ & $5.1 \times 10$ \\
\hline
\end{tabular}

* Local baby mixtures (11)

** Local baby mixtures (12)

The blend mixtures either prepared or local weaning-food mixtures had a negative presumptive test for the presence of coliform bacteria, Bacillus cereus, Staphylococcus aureus and also fungi and yeasts. These results may partially be due to the effect of heat treatments during the preparation of mixtures and mainly are due to heat sterilization of final food mixtures. The obtained results are in agreement with the recommendations of The Egyptian Organization Standard EOS, (1998). Also, these results agreed with those obtained by Emam, (2002) and Abou-Sebaa, (2004). Finally, it could be concluded that both the prepared weaning food mixtures and the studied commercial baby foods were safe for children consumption and free from coliform bacteria, fungi and yeasts. Also, total bacterial counts and psychrophilic bacteria were in the permissible limits according to EOS, (1998). 


\section{References}

Abou-Sebaa, Sherin S., (2004):

Preparation of Baby Food Mixtures Balance in Nutritional Components During Weaning, M.Sc. Thesis, Faculty of Specific Education, Ain Shams Univ., Egypt.

Allam, S.F., (2007):

Preparation and evaluation of some formulae for infant feeding, Ph, D. Thesis, Fac. Of Agric., Cairo Univ., Egypt.

A.O.A.C., (1990):

Official Methods of Analysis, $15^{\text {th }}$ ed., Washington D.C. Association of Analytical Chemists.

A.O.A.C., (1995):

Official Methods of Analysis, $16^{\text {th }}$ ed., Washington D.C. Association of Analytical Chemists.

A.O.A.C., (2000):

Association of Official Analytical Chemists, Official Methods of Analysis, $16^{\text {th }}$ ed., Washington D.C. Association of Analytical Chemists.

Barauh, A.M., Borah, R.C., (1998):

Practical manual on elementary plant biochemistry and chemistry of plant product (pp. 4). BNCA, Assam Agricultural University, Chariali, Assam.

Bligh, E.G. and Dyer, W.J., (1959):

a rapid method of total lipid extraction and purification, Can. J. Biochem. Physiol., 37: 911 - 917.

Daoud, A.A., (2002):

Fortification of some Bakeries. M.Sc. Thesis, Fac. Of Agric., Moshtohor, Zagazig Univ.

Doweider, M.M., (2001):

Chemical and Physical Studies on some Natural Resources Used in Improving Bakery Products. Ph.D. Thesis, Fac. Of Agric., Cairo Univ., Egypt.

Emam, O.A., (1997):

Preparation of low protein cakes, Egyptian J. of Nutrition, Vol. 12 (2): 1-17.

Emam, O.A., (2002):

Preparation of some weaning food mixtures and their nutritional evaluation. Annals of Agric. Sci., Moshtohor, Benha Univ., Egypt, 40 (4): 2161 - 2175.

EOS, (1992):

Egyptian Organization for Standardization and Quality Control, (No. 1805), Ministry of Industry, Cairo, Egypt.

EOS, (1998):

Egyptian Organization for Standardization and Quality Control, No. 135. "Cereal Based and/or legumes Baby Food", Egyptian Organization for Standardization and Quality Control. Ministry of Industry, Cairo, Egypt. 


\section{Osama Abdel Atty Rashwan and Mohamed Farag Mohamady}

FAO/WHO, (1985):

Energy and protein requirement, Report of joint FAOMHO/UNU Expert Consultation. WHO Tech. Rep. Ser. No. 724, WHO, Geneva.

\section{FAO/WHO (1989):}

Protein quality evaluation, report of a joint FAOMHO/UNU Expert Consultation held in Bethesda, Md., U.S.A., Food and Agriculture Organization of the

United Nations, Rome, Italy.

Farag, M.M., (1999):

Effect of Processing on Quality and Nutritive Value of some Weaning Foods, M.Sc. Thesis, Fac. Of Agric., Cairo Univ., Egypt, pp. 204.

Farag, R.S.; Abou Raiia, S.H.; Sidky, H.M.; El-Khawas, K.H. and Abu-El-Anwar, A.A., (1998):

Chemical and biological evaluation of some prepared baby foods. Egyptian J. of Nutr., 13 (2): 82 - 106.

Freig, Shadia, A. (2002):

Preparation and Evaluation of Naturally Flavored Weaning Foods for Protein Energy Malnourished Infants. Ph.D. Thesis, Faculty of Agriculture, Cairo Univ., Egypt.

Gorinstein, S.; Zachweija, Z.; Folta, M.; Barton, H.; Piotrowicz, J.; Zemser, M.; Weisz, M.; Trakhtenberg, S. and Màrtin-Belloso, O., (2001):

Comparative contents of dietary fiber, total Phenolics and minerals in persimmons and apples. J. of Agric. Food Chem., 49: 952 - 957.

Hamed, Thanaa, E.S.,:

Nutritional and Biochemical Studies on some Supplementary Food for Infants. Ph.D. Thesis, Rural Home Economics, Faculty of Agriculture, Cairo University, Egypt.

(ICMSF) International Commission on Microbiological Specification for Foods, (1978): Microorganisms in Food. Univ. of Toronto Press, Toronto and Buffalo, Canada.

Ismail, Ferial A.; Galal, F.S.; El-Atawy Y.S. and Bakry, A.A.,(2000):

Chemical and physical characteristics of Weaning Foods prepared from cereals and legumes, Egypt. J. of Agric. Res., 78 (1): $293-307$.

Khalil, M.M. and Hussein, M.A., (2003):

Chemical and biological studies on sponge cakes fortified with gur flour or its protein isolate. Arab Univ., J. of Agric. Sci., Ain Shams Univ. Egypt, 11 (1): 291 - 301.

Nazih, M. and Rashed, M., (2000):

Nutritional Status of Infants and Preschoolers in a Disprivileged Area in Cairo. J. Bull. Nutr. Inst., Cairo, Egypt, 20(1): 138-156.

Thimmaiah, S.K., (1999):

Standard Methods of Biological Analysis, Kalyani Pub., Ludhiana, 44. 
Egypt. J. of Nutrition and Health Vol. 10 No. 1 (2015)

WHO, (World Health Organization), (1991):

National Strategies forOvercoming Micronutrient Malnutrition Document, EB 89/27. Executive Board, $89^{\text {th }}$ Session.

Winder, K. and Eggum, O.B., (1966):

Effects of short chain fatty acid on a new human colon carcinoma cell (LIMI 215), Gut, 27: 1457 - 1463. 
القيمة الغذائية والصورة الميكروبيولوجية لخلطات من أغذية الفطام المجهزة محلياً

$$
\begin{aligned}
& \text { أسامه عبد العاطي رشوان ومحمد فرج محمدي } \\
& \text { المعهل القومي للتغذية بالقاهزة } \\
& \text { الملخص العربي }
\end{aligned}
$$

الهاف الأساسي من البحث هو محاولة إعاد خلطات للاطفال ذات قيمة غذانية عالية وآمنة ميكروبيولوجياً؛ كما يهاف البحث إلى بلى

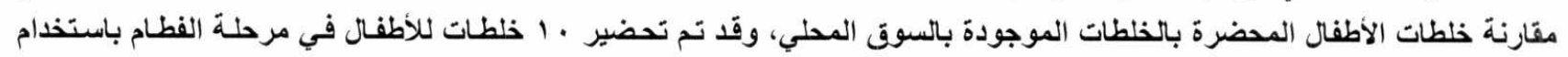

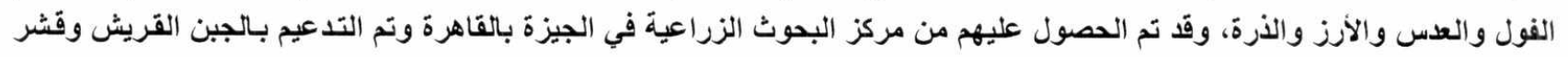

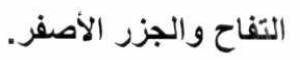

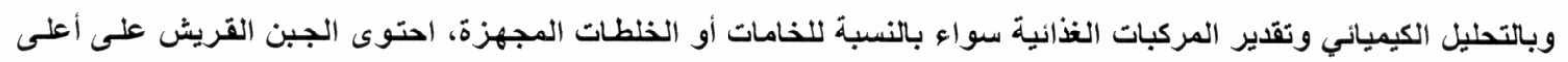

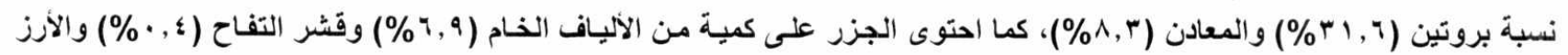

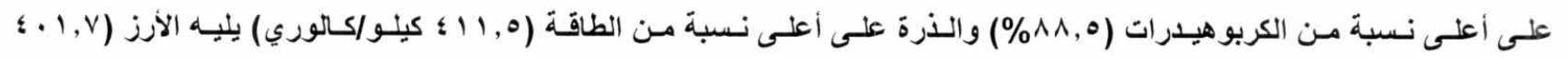

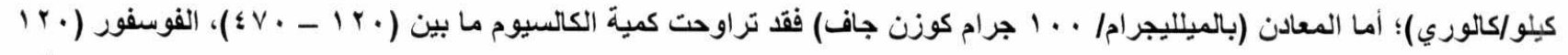

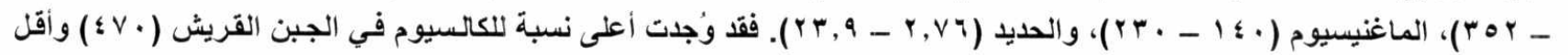

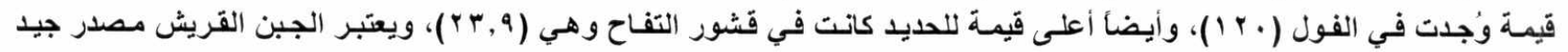
للكالسيوم والفوسفور بينما قُشر التفاح يعتبر المصدر الرئيسي للحديد.

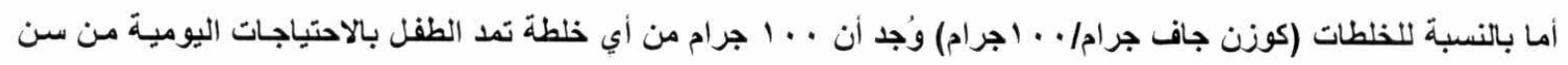

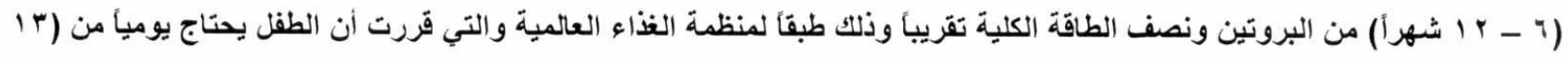

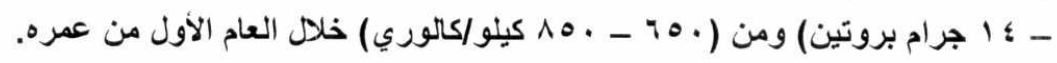

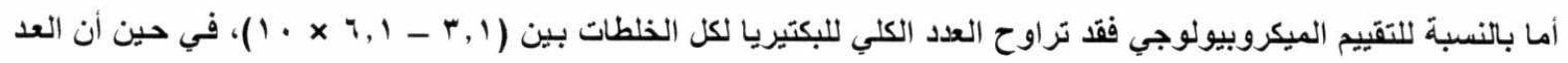



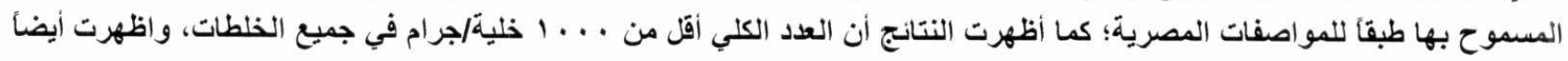

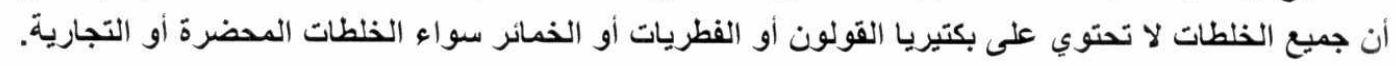

